Maurer School of Law: Indiana University

Digital Repository @ Maurer Law

2011

\title{
The Domestic Face of Globalization: Law's Role in the Integration of Immigrants in the United States
}

\author{
Alfred C. Aman \\ Indiana University Maurer School of Law, aaman@indiana.edu \\ Graham Rehrig \\ Indiana University Maurer School of Law
}

Follow this and additional works at: https://www.repository.law.indiana.edu/facpub

Part of the Civil Rights and Discrimination Commons, and the Immigration Law Commons

\section{Recommended Citation}

Aman, Alfred C. and Rehrig, Graham, "The Domestic Face of Globalization: Law's Role in the Integration of Immigrants in the United States" (2011). Articles by Maurer Faculty. 1281.

https://www.repository.law.indiana.edu/facpub/1281

This Article is brought to you for free and open access by the Faculty Scholarship at Digital Repository @ Maurer Law. It has been accepted for inclusion in Articles by Maurer Faculty by an authorized administrator of Digital Repository @ Maurer Law. For more information, please contact rvaughan@indiana.edu. 
| Article |

\title{
The Domestic Face of Globalization: Law's Role in the Integration of Immigrants in the United States
}

\author{
Alfred C. Aman, Jr.* \& Graham Rehrig*
}

\section{Abstract}

This article applies a global perspective to immigration in the United States, focusing in particular on law's role in the integration of immigrants into U.S. society. The global perspective illuminates the relationship of immigration to other forms of transnationalism, as well as to the situation of non-immigrant minorities and the working poor. We review the history of immigration law in the United States as well as the main elements of current debate. Drawing on the Constitution's guarantees of equal protection, as well as the preemption doctrine, we suggest specific ways in which immigration law might optimally evolve in the future. While information and communication technology are not discussed at length in the paper, we suggest the context in which media pluralism is relevant to a multicultural society.

I Key words : Globalization, Immigration, Integration, United States, Civil Rights, Law Reform

\section{Immigration as the Domestic Face of Globalization}

Immigration draws our attention in vivid ways to fundamental questions of law's role in society - in particular, the role of domestic

\footnotetext{
* Indiana University Maurer School of Law, U.S.A.

The early version of this paper was presented in the SIMS International Conference on "Use and Issues of ICT in Multicultural Society," Sookmyung Women's University, Seoul, Korea, October 2011.

Acknowledgment. Alfred Aman wishes to acknowledge the contributions of Carol Greenhouse, particularly with regard to ethnographic works on the United States cited in the text.
} 
law in relation to the transnational society produced by globalization. Today, society is no longer wholly national in character - if it ever was (Cattelino, 2010; Guarnizo, 2003). This situation yields a disjunction between institutions predicated on the idea of a national society and the reality of transnationalism in the contemporary milieu (Waldlinger, 2007). This disjunction may pose a number of potential dilemmas for domestic law, particularly in contexts in which legal rights and social norms verge on incommensurability, or where regulation meets limits to its applicability in relation to situations that are transnational in scope.

In this article, we consider law's role in immigration from the standpoint of how it may ease some of the sharpest contradictions between the national and transnational aspects of law and society. The themes of information and communication technology are integral to contemporary processes of globalization; communication emerges more specifically in this article along the horizons where the prospects for integration are improved by community development and cross-community involvement. Throughout, our main focus is on law in three main areas: protections against discrimination, the supremacy of national law over local law, and access to resources fundamental to basic social security.

Let us begin with some points of orientation. As a general proposition, we may stipulate that one major role of domestic law is to support the conditions that foster meaningful social, economic, and political participation (Zolberg, 2007, p. 54).1) In today's world, we may think of this role as global in the sense that it is not necessarily or automatically limited to citizens. Moreover, social, economic, and political participation are themselves nowadays transnational in character, particularly for countries in positions of economic power such as South Korea and the United States. This is because globalization is both the cause and effect of relationships, investments, and interests that extend beyond single countries in myriad ways - ranging from the intimately personal to multinational institutions.

Accordingly, understanding the role of domestic law in the current global environment involves two main perspectives. The first is a domestic perspective on globalization, so as to appre-

1) This paragraph and the one following are adapted from Aman, 2004, pp.7-8. 
ciate the extent to which globalization is produced and experienced in highly diverse ways in different times, places and circumstances. Taking a domestic perspective on globalization reminds us that globalization is neither uniform nor somehow "above" society and its institutions; it does not erase or mitigate the specificity of local contexts and concerns. Thus, globalization enlarges the scope for comparison at the same time that it requires us to take into account localized differences, as these are also meaningful.

The second perspective is related to the first: understanding law's role today also means taking a global perspective on domestic affairs. This goes beyond the specific interplay of the local and translocal just described. "Global forces" are not only or wholly the effects of extra-territorial or translocal (transnational) phenomena. They do not necessarily come from beyond national borders or beyond national government. On the contrary, globalization is deeply embedded within domestic institutions, both public and private, as ideas, relations, interests, and effects. For example, in the United States, marketization of social services became politically popular as electorates became newly aware of global economic competition in the 1990s, resulting in a major transformation in both the idea of "the public" and the way the public sector functions in American life (Greenhouse, 2009, 2011). Further examples might involve transnational private sector entities that do business in American communities, such as banks and other services (Aman, 2004).

Understanding immigration requires both of these perspectives, making the question of law's role urgent, challenging, relevant, and fascinating. A global perspective on domestic affairs draws our attention to the arrival of new communities and the question of their integration. But it does not stop there. A domestic perspective on globalization reminds us that the issue of integration does not arise only because of the presence of immigrants. Immigrants are not the only ones for whom integration is unfinished business. In the United States, at least, some of the problems of immigrants are also the problems of the working poor and other populations at the social margins (see Goode \& Maskovsky, 2001; Wacquant, 2009). That said, immigrants have an even steeper mountain to climb since the judiciary has interpreted the law to grant powers to Congress over immi- 
grant status that it would not recognize if only citizens were involved (see further discussion below).

In broader terms, any national society today-if it is a major economic power - is already a transnational society, and already dealing with issues of integration (for native-born persons and immigrants alike) arising from the restructuring of economy, society, and politics associated with its involvement in globalization. It is easy-too easy-to imagine that it is transnational immigrants who introduce the question of national integration; in fact, it is immigrants who give a domestic face to a global situation that has already affected domestic institutions. In this respect, the experiences of South Korea and the United States may be comparable; in what follows we limit ourselves to the United States.

Support for the proposition that even localized domestic affairs are embedded in globalization (as above) may be found in the correspondence between migration flows and global economic conditions, as well as in the ways social policy is made subject to the same market logic as globalization itself. In the United States today, globalization tends to be understood in terms of market pressures, as a force favoring efficiency and seemingly unfettered competition. Many regulatory policy approaches now privilege markets over law. The main regulatory reforms in ascendancy today consist of various forms of deregulation, privatization, and public/private partnerships-with the private sector often performing tasks once reserved primarily for government (Aman, 2004; Freeman \& Minow, 2009).

Indeed, political debates about these reforms usually treat globalization as if it were synonymous with the market, often politically packaged with (or as) ideological assertions about the virtues of markets over bureaucracy. In the United States, the issue of immigration is intertwined with these premises in several ways. The regulation of immigration tends to privilege work, particularly skilled work; under other circumstances, the argument against migration is waged on the grounds of unfair (i.e., under-selling) competition for jobs with the native born. Immigration policy sets heavy bars against migrants who might require government-subsidized social services.

These are essentially efficiency arguments entirely consistent with marketized approaches to other areas of social policy. But immigration also challenges those approaches. Anti-immigration 
critics blame immigrants for restricting the work opportunities of the native born, but not the policies that produce job scarcity. They blame immigrants for working, but also for not working.

But perhaps even more fundamentally, the presence of immigrants brightens the line between law and society, the public and private sectors, and the federal and local levels of governmentsince immigration law is primarily federal, and arenas of reception are local, directly exposed to local social opinion. Immigration is thus at the crux of a number of issues central to the domestic face of globalization: the limits of the market, the limits of law, and the limits of power at the various social and political levels of government and governance-as well as new forms of identity, social mobility and vulnerability.

\section{Immigration in the Context of Globalization}

Since 1950, migration has become increasingly global in terms of the geography of movement, and immigration is increasingly an indicator of receiving countries' status as leaders of global capitalism (Massey, 1990, 1994; Massey et al., 1998). The expansion of global migration has been particularly marked since the 1980s and 1990s, as migration increased worldwide, mainly towards Europe and the United States but also, increasingly, towards new receiving countries -including Korea.

Earlier periods of migration were concentrated in Europe-as sites of both sending and receiving. Prior to 1950, most immigration to Europe was from European colonies; prior to 1925, the vast majority (85 percent) of all migrants were themselves European (Massey, 1994, p. 183). Europe remains an important receiving region, on a par with the United States. While the United States has a long tradition of migration (both internal and external, as a receiving country), U.S. migration patterns since the 1980s share the broad characteristics of the new global migration that countries such as Korea and other newer receiving countries are experiencing. In general, immigration tends to follow paths of investment in reverse (as trade, off-shore manufacturing, or military ventures), as migrants either retrace the paths of investment back to their source in the economically stronger region (Sassen, 1988, ch. 3; Passel \& Fix, 1994; Robinson, 1996) or pursue opportunities in adjacent trading partner countries (Massey, 1994). 
The global context of immigration is important for a discussion of law's role in that process for at least three reasons. First, while the history of world migration involves numerous strands (different sorts of push and pull factors, different opportunities and constraints according to time, location, population, and circumstance), current trends suggest that immigration is a predictable consequence of economic growth in global or transnational terms. This is indicated by recent additions to the list of receiving countries (including Korea, as already noted) and the embeddedness of migration streams in the social relations of transnational economic activity.

Second, the new migration embedded in globalization since the 1980s to some extent mitigates what would otherwise be a significant difference between countries new to immigration (such as Korea) and older receiving countries (such as the United States). For example, in the United States, as in Korea, recent immigration has shifted from Europe to Latin America and Asia. This is a reminder that immigration is not a monolithic or single phenomenon, but one that is extremely diverse even within a single country's experience.

Even in an old "settler" society such as the United States with a long experience of immigration, immigration presents each era, and each receiving zone, with new problems and opportunities. For better or for worse, discontinuity - of policy, problems and opportunities - is a prominent theme in the U.S. story. The classic image of the European migrants of the 19th and early 20th century who filled the ranks of America's manufacturing and extractive industries and remade the United States as "a melting pot" is still the stuff of personal and national myth, but a long way from the 21st century migrants whose security is anchored to the high or low end of the service sector or small business entrepreneurship (Lamphere et al., 1994). The current scene in the United States reflects multiple developments: key sectors of U.S. manufacturing moved offshore, and the United States selectively opened its borders to migration from Taiwan and Southeast Asia, the latter partly in response to political and moral pressures on the United States Congress following the conclusion of the war in Vietnam. All in all, the U.S. law affecting migration and refugee status is a raggedly inconsistent patchwork, subject to frequent revision as political pressures shift in 
direction and substance (Coutin, 2007).

Third, given that immigration is a feature of national economic development in which a vast array of actors in the private sector are also key players, law relating to effective integration of immigrants should be considered in that same context - that is, in relation to other supports for economic growth and social integration in the public and private sectors more generally. By this we do not mean to limit the question of integration to economic growth in the narrow sense (indeed, we argue against this below), but rather in the broadest sense connecting new arrivals to host communities through employment, consumption, investment, and credit as well as through rights associated with citizenship and/or legal residency. Media and communication technologies are particularly important in this larger context, as communication is integral to the practicalities of immigrant life (whether on the path to assimilation or to success within an ethnic enclave, whatever the case may be) as well as to participation in and identification with the civil society of neighborhood, city, region, and nation (Anderson, 1991; Habermas, 1991, 1995).

In this context, it is relevant to observe that immigration both is and is not a national issue. In the United States - as in Korea-immigrants are not evenly distributed across the national landscape. Migration is transnational in scope and largely urban in direct effect. Most immigration to the United States is to a few large coastal cities in New York and California, with secondary migration from those large metropolitan centers to smaller regional cities.2) In this sense, immigration cuts across multiple jurisdictions and levels of government (city, state, and federal) as well as highly divergent social environments. This situation makes immigration law, though primarily federal, a plural legal network, subject to dense and dynamic legal, political, and social cross-pressures. It also means that the question of integration is highly complex along multiple dimensions, and not likely to be amenable to monolithic approaches.

In general, in view of the above, it is fair to say that immi-

2) The 1990 United States Census-relevant as the backdrop to the major legislative reforms of that decade, discussed in this article-reported that one third of all immigrants were living in California, and 14 percent in New York; most of the others were living in just six other states (United States Department of Commerce, 1993). 
gration is not just one topic, but many topics. This is particularly true with respect to the question of law's optimum role in fostering inclusion and integration of migrant communities, given what are inevitably wide-ranging and localized social dimensions of that question in practice. In urban centers that already accommodate a wide range of immigrant and ethnic enclaves, new arrivals may settle relatively easily; in smaller cities or rural areas where diverse nationalities, languages, and cultures may be a novel and unwanted experience for the host community, immigrants may find a hostile reception. In periods of plenty, integration (and not only of immigrants) is relatively well supported by electorates; in periods of scarcity, the political will for expanded processes of inclusion tends to diminish. Gains in the legal sphere may be mitigated by heightened restrictiveness in the social sphere.3)

In the United States, different immigrant streams have had substantially different experiences-complicated by legislation affecting immigration control; the historical and contextual circumstances of their social, economic and political insertion; by race; region; and a host of other factors-including, nowadays, the public and policy emphasis on counter-terrorism (Zolberg, 2007, pp. 52-53). A large monographic literature by sociologists and anthropologists details the particulars of immigrant experience, especially in urban enclaves (see e.g., Chen, 1992; Freeman, 1989; Park, 1997; Zhou, 1992; Zhou \& Bankston, 1998; more generally, see Waters \& Ueda 2007 and infra). The character of local social reception is a complicated question interwoven with other issues of difference (e.g., class, race, ethnicity, and religion) that are also bound up in the vagaries of national, regional, local, and personal experience. Thus, in practice, it is difficult if not impossible to isolate the question of immigrant integration from other aspects of social marginalization and vulnerability that also include the native born. For this reason, our further discussion of law encompasses issues that affect immigrants but not immigrants exclusively - since the issue of integration arises not from the characteristics of immigrant groups but from the capacity of the host community to offer meaningful support, solidarity, and security to everyone through its institutional and interpersonal fabric.

3) See Hobsbawm, 1983 for analysis of "invented traditions" in this context. 
In what follows, we consider the role of law in U.S. immigration primarily from the standpoint of its efficacy in setting basic parameters for the successful integration of immigrants who arrive legally. This statement requires immediate clarification on two fronts. First, what constitutes "success" is open to debate including debates within immigrant communities themselves. In the United States, sociologists and policy makers concerned with integration have shifted their emphasis from assimilation ("Americanization") to enclaves, and from first- to second-generation experience (Kasinitz et al., 2008; Portes et al., 2005; Portes \& Shafer, 2007; Portes \& Zhou, 1993; Rumbaut, 2004, 2005; Waldlinger, 2007).

Second, the distinction between "legal" and "illegal" -at least in the United States - is neither clear nor simple. The distinction is a technical legal one that has been unstable over the years, as different Congresses bring different concerns to its content and application. The distinction is also a social and political one, and this, too, is subject to inconsistency, misrepresentation of a factual nature, as well as misleading stereotyping. In the gray zone between authorized and unauthorized immigration are petitions for asylum, residency, and work-not to speak of many thousands of families divided by their legal status (e.g., parents without status, children with full status) (see Coutin, 2000, 2001, 2007).

In the current anti-immigration climate in the United States, the political debate over immigration appears to be driven in a limiting way by the conflation of immigration in general with unauthorized immigration, particularly from the south, across the border with Mexico. The situation of unauthorized immigrantspopularly known as "illegal aliens" - has been highly politicized, to the point of intense criminalization (such as the 2010 Arizona law making anyone who "appears" to be an unregistered migrant subject to apprehension and detention) and dramatic performances of exclusion (such as the wall recently constructed along part of the U.S.-Mexico border and self-appointed militia patrols). State and local laws affecting immigrants has proliferated in recent years (see Weissbrodt \& Danielson, 2010). Recent legislative proposals such as the creation of a new citizenship category for U.S.-born children of immigrants (who have always enjoyed full legal citizenship status) and enhanced deportation mechanisms are among the consequences of the melding of legal 
and illegal migration in the current political scene. Thus, what may appear to be a bright distinction from a legal standpoint is anything but that in practice.

\section{A Brief History of Immigration Law in the United States}

United States immigration laws, both historically and presently, reflect the conflict between an open-armed welcome of the immigrants and a barbed-wire fence along a border. This legal dichotomy has enticed immigrants into coming to the United States while often marginalizing immigrant groups once they have arrived, turning immigrants into a general class or even a "permanent subcaste" (see Motomura, 2008, p. 2046). Compounding the difficulties in fairly and effectively addressing immigration is the fact that this issue touches everyone in the United States to one extent or another, for the United States is a settler nation - the history of immigration entwined with the history of indigenous sovereignty and displacement. For many Americans, the immediacy of immigration lends considerable emotion to the metamorphosis from "immigrant" to "American."

For decades after its founding, the United States had essentially an open door policy regarding immigration.4) Over the first half of the 1800s, waves of immigrants began to arrive, notably the Irish after the disastrous potato famine of the 1840s. While the Irish experienced de facto discrimination from nativist elements, de jure discrimination against specific immigrant groups began in earnest after thousands of Chinese immigrants came to the United States after the Civil War to work on the rapidly expanding railroad network. Railroad magnates sought and found a cheap workforce in the Chinese immigrants. Chinese immigrants routinely endured discrimination in the form of low wages, verbal and physical abuse, and exhausting work conditions. To compound Chinese immigrants' troubles, Congress enacted the Chinese Exclusion Act of 1882 (Act of May 6, 1882, ch. 126, 22 Stat. 58, repealed by Act of Dec. 17, 1943, ch. 344, 57 Stat. 600), which barred Chinese from entering the United States.

4) A notable exception was the Alien Act of 1798, which gave the President the power to expel an alien that he deemed to be dangerous. 1 Stat. 570 (1798). 
Subsequently, the so-called Gentleman's Agreement of 1907 resulted in Japan prohibiting its citizens from emigrating to the United States, a policy largely stemming from anti-Japanese nativism in California (see Chin, 1998).

American anti-immigrant sentiment was not restricted to Asian and Irish immigrants. Around the turn of the Twentieth Century, millions of immigrants streamed into America, many of them from "non-traditional" immigrant nations in Eastern and Southern Europe. In a blatant display of racism, Congress passed the Immigration Act of 1917 (39 Stat. 874 (1917)) and related statutes, which severely restricted immigration from "undesirable" (that is, non-northern European) source-nations. For example, the Act of 1917 established an "Asiatic Exclusion [from immigration] Zone" that spanned from Turkey in the west through New Guinea in the east and north to the Russian hinterland.

The U.S. Supreme Court also played a significant role in condoning racist and anti-immigrant government practices in the first half of the 1900s, most notably in the 1944 case Korematsu v. United States (323 U.S. 214 (1944)). Fred Korematsu was a California-born U.S. citizen of Japanese immigrant parentage. Following the Japanese attack on Pearl Harbor in December 1941, President Roosevelt's Executive Order 9066 ordered U.S. military authorities on the West Coast to round up Japanese nationals and their U.S.-born children. The rationale was fear of an invasion by Japan, as well as subversive activity by Japanese agents and sympathetic Japanese-American citizens. Korematsu defied this order and was subsequently arrested. The United States Supreme Court upheld the internment order on the grounds that the executive order was legitimate at the time it was issued. The majority rejected the dissent's claim that the government's actions were race-based discrimination directed at U.S. citizens - thereby warranting a "strict scrutiny" analysis - on the grounds that Japanese were excluded on the basis of their nationality, not their race. The pressing national security concerns allowed the government to pass this constitutional hurdle, in the view of the majority. Even at the time of the Court's decision in Korematsu, there was no evidence that Japanese-American citizens were engaging or intended to engage in subversive activity in support of Japan; however, the Court ruled that the concerns-while disproven after the fact-were legitimate at the time. 
To date, the Court has never struck down the Korematsu decision. The case remains a vivid illustration of how the law may affix immigrants with "foreignness" well into the second generation, as well as how proximate are notions of racial difference and nationality.

\section{Current Laws Regarding Legal and Illegal Immigrants}

America's immigration laws liberalized considerably following World War II, perhaps reflecting a broader societal trend towards ensuring equal rights among different ethnic groups. Instead of using race-based immigration quotas, current U.S. immigration law ostensibly aims to bring highly skilled ("desirable") immigrants into the country through a logical and formal legal mechanism, prevent unauthorized immigration, and to incorporate the new immigrants into U.S. society.

The results of U.S. immigration laws have been mixed for all three immigration policy objectives. Congressional statutes have varied significantly over time. Simultaneously, although illegal immigration has now leveled after dropping significantly in recent years (Passel \& Cohn, 2011), its political volatility for Republicans and Democrats is sustained by the image of open floodgates and earlier decades of steady migration. Finally, efforts to incorporate immigrants have varied considerably in their extent and efficacy. Some Americans, including politicians holding elected office, have extolled the virtues of immigrants while at the same time socially marginalizing immigrants through incendiary nativist rhetoric. Moreover, the public response to the attacks of September 11, 2001, has exacerbated the association of immigrants with insecurity such that it is now difficult to discuss immigration and integration wholly independently from a discourse of national security, particularly with respect to migrants who are Muslim and/or from the Middle East.

U.S. immigration law, articulated in Title 8 of the U.S. Code, divides people into one of three categories: citizens, nationals, and aliens. Aliens are either: immigrants-persons who intend to reside in the United States permanently; non-immigrants-those who come on a temporary basis; or unauthorized immigrants that is, undocumented aliens. There are three pathways to per- 
manent residency status: family relationships, jobs, and refugee status. U.S. citizens over twenty-one years old may sponsor a spouse, fiancé(e), or a close family member. U.S. employers may also sponsor an immigrant who fulfills labor certification requirements. Lastly, a potential immigrant may seek refugee status. A variety of disqualifiers, ranging from mental illness to drug addiction, may prevent an otherwise acceptable candidate from legal admission (see 8 U.S.C. 1182).

The U.S. Supreme Court has struggled to reconcile the constitutional rights of immigrants with state and federal laws that would marginalize or exclude them, especially those who are undocumented. For instance, in Plyler v. Doe, the Court held that an immigrant's status (legal or illegal) could not be used by a state (as opposed to Congress) to prevent a child from attending public elementary and secondary schools (457 U.S. 202 (1982)). The Court's ruling, which struck down a Texas law, stated not only that illegal immigrants were entitled to claim the benefits of equal protection under the Fourteenth Amendment,5) but that the Texas law violated the Equal Protection Clause because the law was not rationally related to a substantial state interest (457 U.S. $215,230)$.

While Plyler represents perhaps the apex of immigrant rights in America, other cases have revealed the precarious posture of immigrants in this country. The "plenary power doctrine" grants Congress nearly unfettered discretion to determine who may become a U.S. citizen, as well as to establish a system for retaining or deporting resident immigrants -illegal or legal (Kleindienst $v$. Mandel, 408 U.S. 753, 769-70 (2000)). The extent of Congress' power "over naturalization and immigration [is such that] Congress regularly makes rules that would be unacceptable if applied to citizens" (Demore v. Kim, 538 U.S. 510, 521 (2003)) (internal citation omitted).6) For instance, congressional statutes may do the following: deny an illegal immigrant habeas corpus relief while the immigrant is detained and awaiting deportation (Demore $v$.

5) The Fourteenth Amendment states in relevant part: "No State shall... deprive any person of life, liberty, or property, without due process of law; nor deny to any person within its jurisdiction the equal protection of the laws." U.S. Const. amend. XIV, $\S 1$.

6) Kim held that it was permissible for the government to deny an illegal immigrant habeas corpus relief while the immigrant was detained and awaiting deportation. 
Kim, 538 U.S. 523); discriminate between citizens and resident aliens who have resided in the United States for less than five years when determining Social Security benefits (Mathews v. Diaz, 426 U.S. 67, 69 (1975)); and deny an immigrant entry into the United States based upon race (Yamataya v. Fisher, 189 U.S. 86, 97 (1903). See also Chin, 1998). Accordingly, until the moment of becoming naturalized citizens, immigrants face a risk of formal legal discrimination against them. Compounding this risk is a strong but informal anti-immigration backlash in this country, amplified by the news media in some quarters (see e.g., Román, 2008, pp. 841-843, 847 (likening current anti-immigration paranoia to Orson Welles' famous 1938 War of the Worlds broadcast)).

Federal funding for immigration law enforcement has increased significantly in recent years. For instance, the United States Department of Homeland Security's (DHS) proposed 2012 budget calls for an allocation of $\$ 11.8$ billion dollars to the Customs and Border Protection department, as well as $\$ 5.8$ billion for Immigration and Customs Enforcement (ICE), with accompanying increases in the number of personnel as well as in performance standards (DHS, 2011, pp. 65-75). From 2004 to 2010, the number of Southwest Border Patrol agents doubled from 10,000 to more than 20,500, and Border Patrol and ICE agents made over 460,000 illegal immigrant apprehensions and 392,000 deportations in 2010 alone (DHS, 2011, pp. 66, 68, 79). The 1986 Immigration Reform and Control Act provides for criminal sanctions against employers - especially repeat offenderswho knowingly hire unauthorized immigrants (IRCA, Pub. L. 99-603 § 274a (codified as amended 8 U.S.C. $§ 1324 a)$ ).7) While this law has been on the books for many years, immigration control efforts have often been aimed at unauthorized immigrants themselves, often in much-publicized ICE raids, rather than their domestic employers.

Recently, however, the Obama administration has inverted this trend to target offending employers (see Preston, 2011). This change has been interpreted by some observers, including admin-

7) Employer penalties can be considerable: $\S 1324 a(e)(4)(A)$ imposes a civil penalty in the form of a cease and desist order and fine for first-time offenders; however, for repeat offenders $\S 1324 \mathrm{a}$ (f) applies criminal penalties, including up to a $\$ 3,000$ fine per illegal immigrant and/or a six-month maximum prison sentence. 
istration officials, to mark a notable shift on unauthorized immigration-one characterized by strengthened border protection while also offering resident unauthorized immigrants a potential pathway to citizenship (Ibid.). This latter proposition, however, remains highly contentious, as seen in popular and congressional opposition to the DREAM (Development, Relief and Education for Alien Minors) Act, which was recently reintroduced in the U.S. Senate (S. 952 112th Cong. (2011)). Under the present iteration of the DREAM Act, which has been considered in various forms since 2001, the law would provide conditional permanent residency for illegal aliens if they meet several criteria, including: graduating from a U.S. high school; displaying good moral character; arriving in the United States as minors (either legally or illegally); and residing in the United States for at least five years preceding the law's enactment (Leist, 2011).8)

Immigration enforcement has intensified in recent years due in large part to political pressure to "get tough" on unauthorized immigration. Congressional legislators have responded with a range of methods to curb unauthorized immigration and to isolate immigrants who reside without authorization in the United States. Legislative actions include the following: erecting a fence and increasing police patrols along the U.S.-Mexico border, proposing that English be the only official language, and aggressively working to deport unauthorized immigrants.9) While

8) While it remains to be seen whether Congress will pass the DREAM Act, California has enacted a similar provision, the California Dream Act, which authorizes state- and privately funded scholarships and aid for illegal immigrants at state universities. See Associated Press (2011, Oct. 8). Dream Act becomes law in California. New York Times. Retrieved from http://www.nytimes.com/2011/10/09/us/california-measure-allows-tuition-aid-for-illegal-immigrants.html. Illegal immigrants, however, must wait to qualify for financial aid until after legal residents have applied. Id. Moreover, unlike the federal DREAM Act, the California act does not contain a mechanism for the children of illegal immigrants to become citizens. Id.

9) For a more egregious example of this trend, consider a controversial recent Alabama statute-"the strongest immigration law in the country"-which permits police officers to demand immigration papers during traffic stops, makes unenforceable most contracts that are made with illegal immigrants, and requires schools to verify their students' immigration statuses. Robertson, C. (2011, Oct. 3). After ruling, Hispanics flee an Alabama town. New York Times. Retrieved from http://www.nytimes.com/2011/10/04/ us/after-ruling-hispanics-flee-an-alabama-town.html? r $=2 \&$ hp. Proponents of the law claim that it will drive out illegal immigrants from low-income jobs (e.g., poultry processing), thus freeing up jobs for legal residents. Arizona's immigration statute has also 
these actions have satisfied certain constituencies, they have also isolated both authorized and unauthorized immigrants in the United States, especially persons of Hispanic heritage. As a result of the relentless political and media drumbeat of the threat to the United States from illegal (Hispanic) immigrants, the term "illegal immigrant" has become a racially loaded term, almost invariably describing persons of Hispanic descent, particularly persons of Mexican heritage.

The U.S. Constitution, both explicitly and as interpreted in case law, forbids the federal government from violating a wide range of protected activities, including free speech, search and seizure, and discriminating against persons based upon race, national origin, and religion. These protections are clear in theory but uncertain in practice, given the extent to which civil liberties and security have been set up as trade-offs in the current environment. Such trade-offs do not affect only immigrants, but they do impact immigrants in particular ways. This balancing act continues to be a work in progress, for politicians, courts and the public at large.

\section{Immigration between Politics and Law}

Social and political resistance to immigration, and consequent challenges to law, is a prominent theme in comparative studies of multicultural countries in Europe and North America (see e.g., Calavita, 2005; Minow et al., 2008; Shukla, 2003). Calavita's comparative study of Spain and Italy is a case in point. Until 1985, Italy and Spain received relatively little external migration (although both nations have rich histories as multiethnic societies from at least the Romans onwards). ${ }^{10)}$ In both countries,

drawn intense media scrutiny. The law, which aims to "identify, prosecute, and deport illegal immigrants," requires the carrying of immigration papers and gives police officers the power to stop and question persons who appear to be in the country illegally. See Archibold, R. (2010, Apr. 23). Arizona Enacts Stringent Law on Immigration. New York Times. Retrieved from http://www.nytimes.com/2010/04/24/us/politics/24immig. $\mathrm{html}$. What exactly constitutes "looking like an illegal immigrant" seems strikingly vague, and President Obama has harshly criticized the Arizona law for "undermin[ing] basic notions of fairness that we cherish as Americans, as well as the trust between police and our communities that is so crucial to keeping us safe." Id.

10) For a thorough analysis of immigration in Spain and Italy over the past several deca- 
employers have enlisted immigrants, often from North Africa and Eastern Europe, into low-end occupations: slaughterhouses, sweatshops, construction, and agriculture in Italy; and agriculture, construction, and domestic service in Spain (Calavita, 2005, pp. 60-68). ${ }^{11)}$ Immigrants in Italy and Spain also routinely find themselves the targets of discrimination and prejudice, ranging from selective police actions to exorbitant housing rates (Calavita, 2005, pp. 99-159).12) As a result, destitution and economic exploitation are endemic immigrant experiences (see Daley, 2011) (noting the tens of thousands of homeless African immigrants in Spain who live in shacks in the woods around Spanish towns). ${ }^{13)}$ Even laws aimed at helping immigrants to integrate into society often result in further marginalizing them, leaving holes in legal protections. As Calavita notes, "Italian and Spanish immigration laws emphasize integration, but at the same time treat immigrants exclusively as workers, their legal status contingent on continued work permits" (2005, p. 11). Spanish and Italian immigration laws aim to bring workers into their countries on a short-term basis, calculating their departures as soon as their visas expire-what Ari Zolberg describes as the "wanted but not welcome" syndrome (1987, p. 36). Naturalization is only exceptionally the culmination of the immigrant experience in Italy and Spain.

Integrating new immigrants into U.S. communities also has complex social and legal aspects-all of which are deeply embedded in the larger context of minority experience as well as social security issues affecting all Americans: housing, credit, education, health and other social services, and the dynamics of employment and income status, among other things. Analyzing the

des, see Calavita (2005).

11) Calavita notes that immigrants in Spain are willing to perform tasks that even unemployed Spaniards would not do (2005, p. 68).

12) For instance, foreigners in Spain make up a proportion of the prison population that is twenty-five times higher than the proportion of immigrants in the population (Calavita, 2005, p. 139).

13) The influx of African immigrants to Southern Europe has increased dramatically in recent months in the wake of the Libyan conflict (Cowell and Povoledo, 2011). In the wake of the Great Recession, the economic outlook for native-born Spaniards and Italians is bleak: 21 percent of Spanish workers and eight percent of Italian workers are unemployed (Ross, 2011; Totaro, 2011). 
prospects for integrating immigrants means taking realistic account of the wider forces of concentration and dispersal at work in the social environment generally: losses of real income associated with economic restructuring; loss of upward mobility associated with low-end service sector employment; the de facto ethnic, racial and class segregation of suburbs; the effects of the credit crisis; straitened budgets at the municipal and state level; and - on the legal side - democracy deficit issues and retrenchments in relation to access to civil rights and welfare rights (the latter particularly affecting immigrants) (Aman, 2004; Massey \& Denton, 1993; Newman, 1999).

In short, in the United States, the prospects for integrating immigrants must be regarded as but one dimension of a larger scenario in which the fragmentation of the social environment and polarization in political and economic contexts are increasingly the norm. The domestic face of globalization registers these diverse (and diversifying) effects in ways that make it difficult if not impossible to isolate immigrants from within the broader context that guarantees continued arrivals while simultaneously making their social insertion parlous. This does not mean that immigrants do not face particular keen vulnerabilities unique to their situation-they do, notably but not only in the form of deportation (also known as "removal"). Rather, it means that the tenuousness of their condition is compounded when political scapegoating misleadingly associates immigrants as a class with dependency and subversion of the labor market (or worse). Income security (even high wealth) does not protect individuals from such categorical risks (see e.g., Ong, 1999).

It may be a truism to observe that the gap between legal rights and social realities can be significant; however, it is important to note the particular ways in which immigrants are vulnerable to this gap, as political sentiment singles them out as a class and warrants "solutions" that may materially worsen their condition (e.g., the 1996 U.S. legislative "reforms" that divided immigrant families, terminated welfare benefits, and expanded grounds for deportation). The most promising evidence of successful integration of immigrants comes from sociological and ethnographic accounts from cities where strong neighborhood governance gives ethnic (including immigrant) communities rec- 
ognition and a direct role in local affairs (for U.S. examples, both from New York City, see Dávila, 2004 and Sanjek, 2000).

In the United States, from a legal standpoint, the particular situation of immigrants is best understood against the background of the rights and remedies provided by law to all Americans - with the caution that immigrants face legal risks that citizens do not, as noted above. Primary among the rights that have been fundamental to the successful legal integration of immigrants are the Constitutional and statutory rights of non-discrimination (colloquially known as "equal rights") and the Constitution's Supremacy Clause, asserting the primacy of federal law over state law. For immigrants, the Supremacy Clause is particularly relevant in the current scene, given the energetic efforts on the part of some states (along the southern border and elsewhere) to set their own checks on immigration in excess of what the current federal law allows.

In the United States, the courts have long held that certain kinds of discrimination based on immigration are not allowed. For example, excluding aliens from welfare benefits without Congress's authorization was held unconstitutional in Graham $v$. Richardson (403 U.S. 365 (1971)). But the courts have also deferred to Congress; thus, Graham v. Richardson was in effect overturned by new legislation barring aliens from welfare benefits-among other things (Illegal Immigration Reform and Immigrant Responsibility Act (IIRAIRA) of 1996). In this respect, IIRAIRA is very much "in sync" with the tendency of Congress in recent decades to respond to globalization by favoring markets over rights as the basis for social policy. The provisions excluding immigrants from welfare amounted to a significant portion of the cost savings usually attributed to the Personal Responsibility and Work Opportunity Reconciliation Act of 1996 ("Welfare Reform Act") (Stepick, 2006).

The trend in U.S. law is toward further restriction, and to further press immigration policy generally into the criminalizing discourse of illegal immigration. The constitutional power to do otherwise is there, a resource awaiting mobilization, even as the general political will waxes and wanes-waxing with the liberalization of the 1970s and waning sharply with the contraction of the 1990s and even more so since then. The current anti-immi- 
grant mood of the Congress-driven by the politicization of "illegals," the security crisis, and the economic downturn-has made reform difficult to accomplish in recent years. But the legal structure for improvement is in place with regard to basic benefits, employment and business opportunities, and openings to participate in the political community.

Relevant to such prospects - and to bridging the gap between legal and social inclusion-are communications media and technologies. Neighborhood radio and newspapers have long been integral to immigrant experience in the United States; digital media and cable are just as relevant to the needs of diasporic and transnational communities today. Communication technologies are not substitutes for other forms of legal and social integration, but supplements to those efforts - and potentially crucial to the mobilization of immigrant communities in pursuit of their own interests. While the role of information technologies and communications go beyond the scope of this paper, it is clear that "structural media pluralism" (Klimkiewicz, 2010) is critical to the futures of new multicultural communities produced by globalization.

\section{Conclusion}

An analysis of immigration as a feature of the domestic face of globalization clarifies a potential role for law in positive terms, while at the same time marking some distance between current directions in immigration law and promising directions along other lines. The current political climate has intensified several legal trends in a negative direction: the emphasis on controlling (i.e., curtailing) immigration, the consequent restrictions on admissibility, the further consequence of expanding the category of unauthorized immigration, and the expansion of vulnerability to criminal penalties and deportation. Also among the negative directions of recent immigration law are the increasing disregard for maintaining family units, curtailments on access to benefits, and the resistance to making some provision for children of unauthorized migrants such as the DREAM Act envisioned.

That these recent initiatives are justified by their proponents in market terms offers little assurance that the second-class status of immigrants (whether authorized or unauthorized) does not also di- 
minish the concept of citizenship and legal residency. Indeed, Demore v. Kim, cited above, was the first deportation of a legal resident, and current proposals would limit the citizenship rights of children born in the United States to immigrant parents. As attempts to scroll back the transnational society that is both the cause and effect of global economic leadership, such efforts fly in the face of contemporary reality. International migration to the United States - as noted at the outset - is a function of a range of overseas investments, including off-shoring major elements of the manufacturing sector, as well as less tangible cultural crosscurrents. A more affirmative role for law would begin in the recognition that economic globalization and the transnationalization of society are two inseparable sides of the same coin.

Acknowledging the social reality of globalization would represent a significant shift of perspective not likely to prevail in the Congress anytime soon-but this should not preclude serious discussion of its beneficial consequences. First, it would affirm the Constitution's equal protection provisions as strongly for immigrants as for U.S.-born individuals, reaffirming the plenary power of the federal government over borders and immigration law, and checking the diminishment of the notion of citizenship and civil liberties noted above. Second, it would contribute to a stabilization of admissibility standards, and obviate the use of criminal procedure and deportation as means of controlling immigration. Third, it would shift the political debate over immigration away from the highly misleading nativist stereotypes of a national culture facing a threatening "Other" - towards more constructive debate about investment in human capital through public/private partnerships at the state and local levels. Finally, it would open the political process surrounding immigration to a more evidence-based approach, which even by itself would improve matters by affirming the contributions of even the newest immigrants to the society and economy of the United States. The legal structure is in place for fundamental improvement along these lines; a selective repeal of the most punitive elements of IIRAIRA and passage of the DREAM Act would be constructive accompaniments. The criteria by which integration may be judged a success are inevitably specific to generational experience and other contextual 
factors; however, if the lessons of the past are any guide to the future in the United States, open doors, strong commitments to civil liberties, investment in education and social security, fair labor standards, and protections for worker safety merit consideration as means of expanding the common cause between immigrants and their citizen neighbors. 


\section{References}

Aman, A. C. (2004). The Democracy Deficit: Taming Globalization through Law Reform. New York, NY: New York University Press.

Anderson, B. (1991). Imagined Communities. London, UK: Verso. (Revised ed.).

Calavita, K. (2005). Immigrants at the Margins: Law, Race, and Exclusion in Southern Europe. New York, NY: Cambridge University Press.

Cattelino, J. (2010). Anthropologies of the United States. Annual Review of Anthropology, 39, 273-292.

Chen, H. (1992). Chinatown No More: Taiwan Immigrants in Contemporary New York. Ithaca, NY: Cornell University Press.

Chin, G. J. (1998). Segregation's Last Stronghold: Race Discrimination and the Constitutional Law of Immigration. UCLA Law Review, 46(1), 13.

Coutin, S. (2000). Legalizing Moves: Salvadoran Immigrants' Struggle for U.S. Residence. Ann Arbor, MI: University of Michigan Press.

Coutin, S. (2001). The Oppressed, the Suspect, and the Citizen: Subjectivity in Competing Accounts of Political Violence. Law and Social Inquiry, 26(1), 63-94.

Coutin, S. (2007). Nations of Emigrants: Shifting Borders of Citizenship in El Salvador and the United States. Ithaca, NY: Cornell University Press.

Cowell, A. \& Povoledo, E. (2011, May 10). U.N. Urges Ships to Help Migrants in Mediterranean. New York Times. Retrieved from http://www.nytimes.com/2011/05/10/world/africa/10migrants.html.

Daley, S. (2011, May 26). Chasing Riches from Africa to Europe and Finding Only Squalor, New York Times. Retrieved from http://www.nytimes.com/2011/05/26/world/europe/ 26migrants.html?_r=1\&hp.

Dávila, A. (2004). Barrio Dreams: Puerto Ricans, Latinos, and the Neoliberal City. Berkeley, CA: University of California Press. 
Freeman, J. (1989). Hearts of Sorrow: Vietnamese-American Lives. Stanford, CA: Stanford University Press.

Freeman, J. \& Minow, M. (Eds.). (2009). Government by Contract: Outsourcing and American Democracy. Cambridge, MA: Harvard University Press.

Goode, J. \& Maskovsky, J. (Eds.). (2001). The New Poverty Studies: The Ethnography of Power, Politics, and Impoverished People in the United States. New York, NY: New York University Press.

Greenhouse, C. J. (2011). The Paradox of Relevance: Ethnography and Citizenship in the United States. Philadelphia, PA: University of Pennsylvania Press.

Greenhouse, C. J., (Ed.). (2009). Ethnographies of Neoliberalism. Philadelphia, PA: University of Pennsylvania Press.

Guarnizo, L. E. (2003). The Economics of Transnational Living. International Migration Review, 37(Fall), 666-699.

Habermas, J. (1991). The Structural Transformation of the Public Sphere: An Inquiry into a Category of Bourgeois Society. (Burger, T. \& Lawrence, F., Trans.). Cambridge, MA: Harvard University Press.

Habermas, J. (1995). Citizenship and National Identity: Some Reflections on the Future of Europe. In R. Beiner (Ed.), Theorizing Citizenship (pp. 255-281). Albany, NY: SUNY Press.

Hobsbawm, E. J. (1983). Mass-producing Traditions: Europe, 1870-1914. In E. J. Hobshawm, \& T.O Ranger (Eds.), The Invention of Tradition (pp. 263-306). Cambridge, UK: Cambridge University Press.

Kasinitz, P., Mollenkopf, J. H., Waters, M.C., \& Holdaway, J. (2008). Inheriting the City: The Children of Immigrants Coming of Age. New York, NY: Russell Sage Foundation.

Klimkiewicz, B. (2010). Structural media pluralism. International Journal of Communication 4, 906-913. Retrieved from http://ijoc.org/ojs/index/php/ijox/article/view/789/465.

Lamphere, L., Stepick, A., \& Grenier, G. J. (Eds.). (1994). Newcomers in the Workplace: Immigrants and the Restructuring of the U.S. Economy. Philadelphia, PA: Temple University Press.

Leist, L. (2011, May 11). Senate Dems Re-introduce DREAM Act, NBC News First Read. Retrieved from http://firstread.msn 
bc.msn.com/_news/2011/05/11/6624870-senate-dems-re-introduce-dream-act.

Massey, D. S. (1990). Social Structure, Household Strategies, and the Cumulative Causation of Migration. Population Index, 56, 326.

Massey, D. S. (1994). The Social and Economic Origins of Immigration. Retrieved from http://www.thesocialcontract.com/pdf/four -three/massey.pdf.

Massey, D. S. \& Denton, N. A. (1993). American Apartheid: Segregation and the Making of the Underclass. Cambridge, MA: Harvard University Press.

Massey, D., Arango, J., Hugo, G., Kouaouci, A., Pellegrino, A., \& Taylor, J. E. (1998). Worlds in Motion: Understanding International Migration at the End of the Millennium. Oxford, UK: Clarendon Press.

Minow, M., Shweder, R.A., \& Markus, H. R. (Eds.). (2008). Just Schools: Pursuing Equality in Societies of Difference. New York, NY: Russell Sage Foundation.

Motomura, H. (2008). Immigration Outside the Law. Columbia Law Review, 108(8), 2037-2097.

Newman, K. S. (1999). Falling from Grace: Downward Mobility in the Age of Affluence. Berkeley and Los Angeles, CA: University of California Press.

Ong, A. (1999). Flexible Citizenship: The Cultural Logics of Transnationality. Durham, NC: Duke University Press.

Park, K. (1997). The Korean American Dream: Immigrants and Small business in New York City. Ithaca, NY: Cornell University Press.

Passel, J. S. \& Fix, M. (1994). U.S. Immigration in the Global Context: Past, Present, and Future. Indiana Journal of Global Legal Studies, 2(1), 5-20.

Pew Hispanic Center. (2011). Unauthorized Immigrant Population: National and State Trends. Washington, DC: Passel, J. S. \& Cohn, D. Retrieved from http://pewhispanic.org/reports/ report.php?ReportID=133.

Portes, A. (1999). Immigration Theory for a New Century: Some Problems and Opportunities. In C. Hirschman, P. Kasinitz, 
\& J. DeWind (Eds.), The Handbook of International Migration: The American Experience (pp. 21-33). New York, NY: Russell Sage Foundation.

Portes, A. (2006). Institutions and Development: A Conceptual Re-analysis. Population and Development Review, 32(June), 233 $-262$.

Portes, A. (2008). Migration and Social Change: Some Conceptual Reflections (address given at Oxford University, July 1, 2008). Retrieved from http://www.imi.ox.ac.uk/pdfs/alejandro-portes-migration-and-social-change-some-coceptualreflections

Portes, A. \& Rumbaut R. G. (2006). Immigrant America: A Portrait (3rd ed.). Berkeley, CA: University of California Press.

Portes, A., Fernandez-Kelly, P., \& Haller, W. (2005). Segmented Assimilation on the Ground: The New Second Generation in Early Adulthood. Ethnic and Racial Studies, 28(Nov.), 1000 -1040 .

Portes, A., \& Shafer, S. (2007). Revisiting the Enclave Hypothesis: Miami Twenty-five Years Later. Research in the Sociology of Organizations, 25, 157-190.

Portes, A., \& Zhou, M. (1993). The New Second Generation: Segmented Assimilation and Its Variants among Post-1965 Immigrant Youth. The Annals of the American Academy of Political and Social Sciences, 530, 74-96.

Preston, J. (2011, May 30). A Crackdown on Employing Illegal Workers. New York Times. Retrieved from http://www.nyti mes.com/2011/05/30/us/politics/30raid.html?pagewanted= all.

Román, E. (2008). The Alien Invasion? Houston Law Review, 45(3), 841-899.

Robinson, W. (1996). Promoting Polyarchy: Globalization, U.S. Intervention, and Hegemony. Cambridge, UK: Cambridge University Press.

Ross, E. (2011, April 29). Spanish Unemployment Rate Rises to More than $21 \%$ as Inflation Accelerates. Bloomberg. Retrieved from http://www.bloomberg.com/news/2011-04-29/spanish-unemployment-rate-rises-to-more-than-21-as-inflation-accelerates. html.

Rumbaut, R. G. (2004). Ages, Life Stages, and Generational Cohorts: 
Decomposing the Immigrant First and Second Generations in the United States. International Migration Review, 38(Fall), 1160-1205.

Rumbaut, R. G. (2005). Turning Points in the Transition to Adulthood: Determinants of Educational Attainment, Incarceration, and Early Childbearing among Children of Immigrants. Ethnic and Racial Studies, 28(Nov.), 1041-1086.

Sanjek, R. (2000). The Future of Us All: Race and Neighborhood Politics in New York City. Ithaca, NY: Cornell University Press.

Sassen, S. (1988). The Mobility of Labor and Capital. Cambridge, UK: Cambridge University Press.

Saxenian, A. (2006). The New Argonauts: Regional Advantage in A Global Economy. Cambridge, MA: Harvard University Press.

Shukla, S. R. (2003). India Abroad: Diasporic Cultures of Postwar America and England. Princeton, NJ: Princeton University Press.

Stepick, A. (2006). "There Is More to Life than a Glass of Water": Immigration in the Contemporary United States. American Anthropologist, 108(2), 392-396.

Susser, I. (1998). Inequality, Violence, and Gender Relations in A Global City: New York, 1986-1996. Identities, 5(2), 219-247.

Totaro, L. (2011, May 31). Italy Unemployment Rate Declined in April as Production Outlook Improves, Bloomberg. Retrieved from http://www.bloomberg.com/news/2011-05-31/italyunemployment-rate-declined-in-april-as-production-outloo k-improves.html.

United States Department of Commerce, Economics and Statistics Administration, Bureau of the Census (1993). We the American … Foreign Born. Washington, DC. Retrieved from http://www.census.gov/apsd/wepeople/we-7/pdf.

United States Department of Homeland Security (2011). FY 2012 Budget in Brief. Washington, DC. Retrieved from http://www. dhs.gov/xlibrary/assets/budget-bib-fy2012.pdf.

Wacquant, L. (2009). Punishing the Poor: The Neoliberal Government of Social Insecurity. Durham, NC: Duke University Press.

Waldlinger, R. (2007). Transforming Foreigners into Americans. In M. C. Waters \& R. Ueda, \& H. B. Marrow (Eds.), The New 
Americans: A Guide to Immigration Since 1965 (pp. 137-148). Cambridge, MA: Harvard University Press.

Waters, M. C. \& Ueda, R. (Eds.). (2007). The New Americans: A Guide to Immigration Since 1965. Cambridge, MA: Harvard University Press.

Weissbrodt, D. \& Danielson, L. (2010). Immigration Law and Procedure in a Nutshell. Eagan, MN: West Publishing. (6th ed.)

Zhou, M. (1992). New York's Chinatown: The Socioeconomic Potential of An Urban Enclave. Philadelphia, PA: Temple University Press.

Zhou, M. \& Bankston III, C. L. (1998). Growing up American: How Vietnamese Children Adapt to Life in the United States. New York, NY: Russell Sage Foundation.

Zolberg, A. R. (1987). Wanted but Not Welcome: Alien Labor in Western Development. In W. Alonso (Ed.), Population in An Interacting World (pp. 36-73). Cambridge, MA: Harvard University Press.

Zolberg, A. R. (2007). Immigration Control Policy: Law and Implementation. In M. C. Waters \& R. Ueda (Eds.), The New Americans: A Guide to Immigration Since 1965 (pp. 29-55). Cambridge, MA: Harvard University Press.

\section{Cases Cited}

Demore v. Kim, 538 U.S. 510 (2003).

Graham v. Richardson, 403 U.S. 365 (1971).

Kleindeinst v. Mandel, 408 U.S. 753 (2000).

Korematsu v. United States, 323 U.S. 214 (1944).

Mathews v. Diaz, 426 U.S. 67 (1975).

Plyler v. Doe, 457 U.S. 202 (1982).

Yamataya v. Fisher, 189 U.S. 86 (1903).

\section{Laws and Statutes Cited}

Alien Act of 1798, 1 Stat. 570 (1798).

Chinese Exclusion Act of 1882, 22 Stat. 58 (1882). 
Development, Relief, and Education for Minors (DREAM) Act, S. 952, 112th Congress (2011).

Illegal Immigration Reform and Immigrant Responsibility Act (IIRAIRA), P. L. 104-208 (1996).

Immigration Act of 1917, 39 Stat. 874 (1917).

Immigration Reform and Control Act (IRCA), P. L. 99-603 (1986).

Inadmissable Aliens, 8 U.S.C. 1182 (2011).

Personal Responsibility and Work Opportunity Reconciliation Act (PRWORA), P. L. 104-193 (1996).

\section{Biographical Note}

Dr. Alfred C. Aman, Jr. is the Roscoe C. O'Byrne Professor of Law at Indiana University Maurer School of Law, in Bloomington, Indiana. Professor Aman is the former dean at Indiana University-Bloomington and Suffolk University law schools. He is the founding editor and current faculty editor of the Indiana Journal of Global Legal Studies. A specialist in administrative law, he has published widely on globalization in relation to domestic law.

E-mail: aaman@indiana.edu

Graham Rehrig took his undergraduate degree at Duke University. He is a third-year law student at Indiana University Maurer School of Law, where he is editor-in-chief of the Indiana Law Journal.

E-mail: grehrig@indiana.edu

Date of submission of the article: September 5, 2011

Date of peer-review: November 24, 2011

Date of the confirmation of the publication: November 24, 2011 